\title{
BMJ Open Quality GP request rejections: an analysis for ultrasound service improvement at one centre
}

\author{
Margaret Ann Taylor (i) ${ }^{1,2}$
}

To cite: Taylor MA. GP request rejections: an analysis for ultrasound service improvement at one centre. BMJ Open Quality 2020;9:e001108. doi:10.1136/ bmjoq-2020-001108

Received 10 July 2020 Revised 17 August 2020 Accepted 30 August 2020
Check for updates

(C) Author(s) (or their employer(s)) 2020. Re-use permitted under CC BY-NC. No commercial re-use. See rights and permissions. Published by BMJ.

${ }^{1}$ Clinical Radiology, NHS Tayside, Dundee, UK

${ }^{2}$ Clinical Radiology, Perth Royal Infirmary, Perth, UK

Correspondence to Margaret Ann Taylor; margaret.taylor6@nhs.scot

\section{INTRODUCTION}

Balancing capacity with demand and ensuring observance of local referral guidance and that patients receive the correct investigation are key to the delivery of a busy ultrasound scanning service. This centre has a gynaecology tertiary referral unit with a dedicated ultrasound service. In parallel, the clinical radiology ultrasound service provides diagnostic gynaecology scans for general practitioners (GPs). We received informal reports of GP gynaecology ultrasound requests being 'inappropriately' rejected by the radiology department sonographer-led service, and this short report outlines the assessment made. Prior to this audit being done, gynaecology and radiology had collaborated to provide joint referral guidance to GPs, but anecdotally there appeared to still be referrer confusion. We reviewed the information provided by GPs on requests, to determine why they were rejected and identify any associated sonographer service improvements and/or training needs. It is well understood that robust sonographic clinical governance processes are difficult to implement and interpret effectively, ${ }^{1}$ but all possible review and reflective processes should be explored to improve service quality.

\section{METHODS}

Retrospectively, 272 sonographer-rejected gynaecological ultrasound requests submitted by GPs over a 12-month period (2018) were examined.

- We reviewed the clinical information provided on the request and the sonographer comments.

- We reviewed individual sonographer justification patterns to identify differing practices within the team, which may identify any educational needs. From a team of 12 staff members, 3 were excluded due to long-term absence or job change during the review period. One limitation of this comparison strategy is that the review is an evaluation within a local team standard rather than benchmarked against a wider national standard.

- Any highlighted changes to practice and sonographer support were implemented and a follow-up audit of justification patterns was repeated the following year (2019).

- To measure and determine the impact of improvements made, the 2019 audit results were then compared with the benchmark 2018 audit results.

\section{RESULTS}

Table 1 summarises the reasons given for request rejections. A rejection rate of 272 from 5234 requests equates to $5.2 \%$. This was noted to be comparableto all radiology request rejections.

The top two rejection reasons were postmenopausal bleeding and pregnancy-related disorders, for example, bleeding after termination or possible retained products of conception. Both are inappropriate radiology referrals in this centre and should be referred to specialist gynaecology/obstetrics clinics.

Forty-six requests were rejected as it was unclear what clinical question was being asked, or they were rejected for a more administrative-related clarification. These were not 'rejections' as such but requests for further detail and reflect poor-quality information by the referrer.

One area prompting further exploration was when the GP stated a patient was 'referred to gynaecology' (17). In a bid to reduce duplication of work between services, this statement often initiated an immediate rejection whether any additional supporting clinical information was provided or not. However, it was not always clear if the gynaecology referral had been done already or the GP was awaiting the ultrasound result before deciding. This highlighted a confusing area of responsibility 


\section{Table 1 Results}

\section{Summarised reasons for the 272 GPreferred gynaecology request rejections (sonographer comments)}

\begin{tabular}{|c|c|c|}
\hline Count of patients & $\begin{array}{l}\text { Requests } \\
\text { rejected }\end{array}$ & $\begin{array}{l}\text { Total } \\
\text { rejections } \\
(\%)\end{array}$ \\
\hline Postmenopausal bleeding & 82 & 30 \\
\hline Pregnancy-related & 56 & 20 \\
\hline $\begin{array}{l}\text { Insufficient clinical detail on } \\
\text { request, 'please clarify' }\end{array}$ & 46 & 17 \\
\hline $\begin{array}{l}\text { Gynaecology referral already } \\
\text { made }\end{array}$ & 17 & 6.5 \\
\hline Reason for rejection unclear & 12 & 4.5 \\
\hline $\begin{array}{l}\text { Inappropriate referral does not } \\
\text { match clinical details }\end{array}$ & 12 & 4.5 \\
\hline Fertility (refer to fertility service) & 11 & 4 \\
\hline $\begin{array}{l}\mathrm{CT} / \mathrm{MRI} / \text { recent scan (no longer } \\
\text { required) }\end{array}$ & 9 & 3.5 \\
\hline $\begin{array}{l}\text { Gynaecology follow-up scan } \\
\text { (no previous radiology imaging } \\
\text { available) }\end{array}$ & 8 & 3 \\
\hline $\begin{array}{l}\text { Groin pain (refer to surgical } \\
\text { service) }\end{array}$ & 6 & 2 \\
\hline $\begin{array}{l}\text { Already known to gynaecology } \\
\text { service with complex history }\end{array}$ & 4 & 1.5 \\
\hline $\begin{array}{l}\text { Urology clinical (gynaecological } \\
\text { scan not indicated/refer to } \\
\text { urology) }\end{array}$ & 3 & 1 \\
\hline $\begin{array}{l}\text { Duplicate requests (requests } \\
\text { joined) }\end{array}$ & 3 & 1 \\
\hline $\begin{array}{l}\text { DVT (pelvic ultrasound not } \\
\text { indicated) }\end{array}$ & 1 & 0.5 \\
\hline Reject error (reinstated) & 1 & 0.5 \\
\hline $\begin{array}{l}\text { Ovarian cancer screening (no } \\
\text { clinical indication) }\end{array}$ & 1 & 0.5 \\
\hline Grand total & 272 & \\
\hline
\end{tabular}

DVT, Deep Venous Thrombosis; GP, general practitioner.

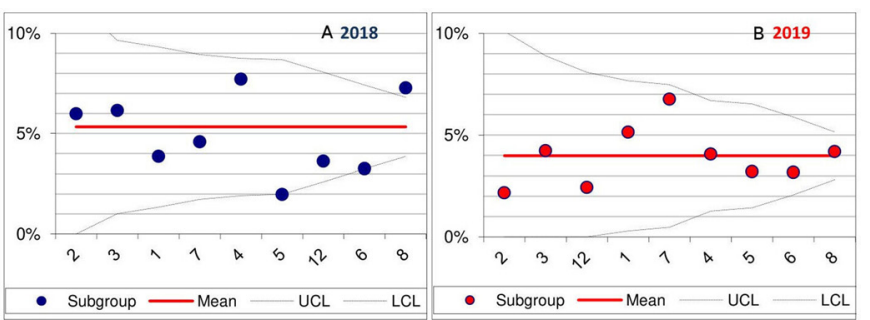

Figure 1 Funnel plot graphs: A 2018 versus B 2019 comparison. Anonymised sonographer $(n=9)$ rejection rate $(\%$ rejected from vetting workload) for 12 months. Subgroup year 2019 shows the mean rejection rate has decreased (to less than 5\%) compared with subgroup year 2018 (mean=5.2\%). Subgroup year 2019 demonstrates tighter 'clustering' around the mean for the team as a whole with less variation and outliers, signifying more consistent vetting practice compared with subgroup year 2018. LCL, lower control limit; UCL, upper control limit. that required further pathway clarification between radiology and gynaecology.

We then reviewed each sonographer's rejection rate benchmarked to the activity of their peers. Figure 1A demonstrates variations in practice in 2018. Any sonographer that falls within the 'funnel' is statistically indistinguishable and outside the funnel is a statistical outlier. Outliers do not necessarily mean poor working practice and can reflect other reasonable causes of variation such as newer qualified/less experience but still signify a potential training need.

\section{IMPROVEMENTS AND UPDATED RESULTS}

More collaborative working relationships were fostered between radiology, gynaecology and the GP primary care community throughout the subsequent year (2019). Patient pathways were reviewed and more open multidisciplinary discussion encouraged. Strategies to reduce duplication of work across ultrasound services were progressed. A joint clinical effectiveness meeting was held early in 2019 and another is planned. These will hopefully continue long term.

Sonographer peer review and group supervision meetings were prioritised as an important supportive forum for professional development.

For fear of being overlooked, rather than one single communication of the audit findings to GPs, we elected for ongoing individual feedback when requests were rejected and sonographers were supported on how to do this effectively. Providing clearer reasoning around why a referral was rejected in an ongoing case-by-case process has been reported to be more effective for referrers. ${ }^{2}$

We then repeated the sonographer review for 2019. Figure 1B shows improvement with a decrease in rejections overall and a more consistent team pattern of request vetting.

\section{CONCLUSION}

This project supports positive collaboration between services with subsequent improvement in the vetting and justification process. In addition, group review meetings have established a worthwhile forum that encourages informative discussion, allowing peer comparison of practice and an improved, consistent team and service approach to referral vetting. A further audit may be appropriate to assess for any rejection patterns specific to individual GPs or community practices, which could then be individually addressed. A limitation of the study was not doing a second review of referrer requests in 2019 as we focused more on sonographer practice. Assessing referrer changes in practice would add to the overall audit results and further audits will include this.

In conclusion we have initiated a process of ongoing service improvements for referrers and patients, supporting clearer multidisciplinary patient pathways and areas of responsibility with a more confident sonographic workforce. 
Contributors MAT was responsible for the study design, data collection, data analysis, drafting of the manuscript and revisions.

Funding The authors have not declared a specific grant for this research from any funding agency in the public, commercial or not-for-profit sectors.

Competing interests None declared.

Patient and public involvement Patients and/or the public were not involved in the design, or conduct, or reporting, or dissemination plans of this research.

Patient consent for publication Not required.

Provenance and peer review Not commissioned; externally peer reviewed.

Open access This is an open access article distributed in accordance with the Creative Commons Attribution Non Commercial (CC BY-NC 4.0) license, which permits others to distribute, remix, adapt, build upon this work non-commercially, and license their derivative works on different terms, provided the original work is properly cited, appropriate credit is given, any changes made indicated, and the use is non-commercial. See: http://creativecommons.org/licenses/by-nc/4.0/.

ORCID iD

Margaret Ann Taylor http://orcid.org/0000-0002-4473-0027

\section{REFERENCES}

1 Parker PC, Byass OR. Successful implementation of a performancerelated audit tool for sonographers. Ultrasound 2015;23:97-102.

2 Eccles M, Steen N, Grimshaw J, et al. Effect of audit and feedback, and reminder messages on primary-care radiology referrals: a randomised trial. Lancet 2001;357:1406-9. 